\title{
Depositional setting of the deep-sea sediments from an area of high nodule occurrence in the Clarion-Clipperton Fractures Zone, NE Pacific
}

\author{
ZLATKA MILAKOVSKA ${ }^{1}$, VALCANA STOYANOVA ${ }^{2}$, \\ ATANAS HIKOV ${ }^{1}$, TOMASZ ABRAMOWSKI ${ }^{2}$, ELITSA \\ STEFANOVA ${ }^{1}$, IRENA PEYTCHEVA ${ }^{1}$, SILVIA \\ CHAVDAROVA $^{1}$ AND MILEN STAVREV $^{1}$ \\ ${ }^{1}$ Geological Institute at the Bulgarian Academy of Sciences \\ ${ }^{2}$ Interoceanmetal Joint Organization \\ Presenting Author: zlatkam@geology.bas.bg
}

Deep-sea sediments from an area bearing high nodule occurrence in the eastern part of the Clarion-Clipperton Fractures Zone, NE Pacific were collected from 4,300-4,500-m depth during the 2019 Interoceanmetal cruise. Box-core samples from six stations were studied to assess their natural variability.

The on board processing documented light brown siliceous silty clay down to $45-\mathrm{cm}$ with a semiliquid dark brown clay variety (7-12 cm thickness) on the top denoted as geochemically active layer (GAL). The GAL Eh ranged between +462 and +545 $\mathrm{mV}$ and decreased with depth. The respective $\mathrm{pH}$ data varied in short span (7.01-7.52).

Bulk sample analysis indicate very fine sandy fine silts. The sediments are predominantly poorly sorted and show polymodal particle size distribution. The silt (50-84\%) and sandy (9-31\%) fractions show opposite trends, whereas the clayey fraction increases with depth.

An amorphous phase (84-88\%) predominates, representing biogenic opal, authigenic Fe-Mn (hydr)oxides and clay minerals. This phase composition defines the sediments as clayey siliceous ooze. The crystalline phases illite, kaolinite, chlorite, quartz, andesine represent a detrital component, as halite, cristobalite and barite are of authigenic origin.

The chemical composition corresponds to pelagic sediments having higher concentration of $\mathrm{Na}, \mathrm{S}, \mathrm{Sr}, \mathrm{Ba}, \mathrm{Sc}, \mathrm{Ge}, \mathrm{Cu}, \mathrm{W}, \mathrm{Y}$, MREE, HREE and lower concentration of $\mathrm{Al}, \mathrm{Si}, \mathrm{Fe}, \mathrm{Mn}, \mathrm{P}, \mathrm{V}$, $\mathrm{Zr}, \mathrm{Nb}, \mathrm{Pb}, \mathrm{As}, \mathrm{Mo}, \mathrm{Ce}$. The sediments have high $\mathrm{Al} /(\mathrm{Al}+\mathrm{Fe}+\mathrm{Mn})$ ratio $(0.57)$ and should be considered nonmetalliferous. Manganese content $(0.16-0.70 \%)$ and the $\mathrm{Mn} / \mathrm{Fe}$ ratio $(0.03-0.16)$ are the highest in the surface layer and decrease in depth. Cobalt, $\mathrm{Ni}$ and $\mathrm{Cu}$ reveal their highest concentrations in the GAL. The different ternary diagrams classify samples as hydrothermal/ hydrogenetic metalliferous sediments. NASC and PAAS-normalized REE patterns show MREE and HREE enrichment with strong negative $\mathrm{Ce}$ and weak positive $\mathrm{Eu}$ and $\mathrm{Y}$ anomalies. Chondrite-normalized REE patterns bear negative $\mathrm{Ce}$ and $\mathrm{Eu}$ anomalies.

The studied sediments reveal polygenic origin. The negative Ce anomaly is in agreement with Eh values, redox sensitive oxides and barite presence, all reflecting the oxidizing environment of formation.

Acknowledgements: The study was supported by Bulgarian National Science Fund grant KP-06-N34/6 